\title{
Reproductive morphology of female Guiana dolphins (Sotalia guianensis)
}

\author{
ESTELLA Z. BECEGATO ${ }^{1,2}$, JANAINA P. ANDRADE ${ }^{1,3}$, JULIANA P. GUIMARÃES ${ }^{1,4}$, \\ JOCIERY E. VERGARA-PARENTE ${ }^{4}$, MARIA ANGELICA MIGLINO ${ }^{1}$ \\ and FERNANDA M. DE OLIVEIRA E SILVA ${ }^{1,4}$ \\ ${ }^{1}$ Pós-Graduação em Anatomia dos Animais Domésticos e Silvestres, Departamento de Cirurgia, \\ Faculdade de Medicina Veterinária e Zootecnia, Universidade de São Paulo, Av. Prof. Dr. \\ Orlando Marques de Paiva, 87, Cidade Universitária, 05508-270 São Paulo, SP, Brasil \\ ${ }^{2}$ Universidade Bandeirante de São Paulo, Faculdade de Medicina Veterinária, Campus ABC, \\ Av. Rudge Ramos, 1501, Rudge Ramos, 09636-000 São Bernardo do Campo, SP, Brasil \\ ${ }^{3}$ Universidade do Grande ABC, Faculdade de Medicina Veterinária, \\ Av. Industrial, 3330, Campestre, 90080-511 Santo André, SP, Brasil \\ ${ }^{4}$ Fundação Mamíferos Aquáticos, Núcleo de Estudo dos Efeitos Antropogênicos nos Recursos \\ Marinhos, Av. Tancredo Neves, 5655, $1^{\circ}$ Andar, Jabotiana, 49095-000 Aracaju, SE, Brasil
}

Manuscript received on August 27, 2014; accepted for publication on December 18, 2014

\begin{abstract}
The reproductive morphology of cetaceans is poorly studied and, despite the large number of strandings, reports on this subject are scarce due to access to carcasses mostly in an advanced state of decomposition. The present study aimed to describe histological characteristics of the female genital tract of Sotalia guianensis, in order to assist in future studies on the reproductive biology of these animals. Females of different ages, from stranding events on beaches in northeastern Brazil, were used. Fragments of all organs were collected and processed for light and scanning electron microscopy. Histological analyses showed that these structures were similar to those found in terrestrial mammals, with some peculiarities, such as the presence of differentiated cells in the vulvar subepidermal layer, not described in the literature on cetaceans. Reproductive studies with a morphological description of the female genital organs are extremely important, since they would enable a better understanding of the species reproductive physiology and assist in the development of new strategies for the species conservation.
\end{abstract}

Key words: Female genital system, anatomy, histology, Guiana dolphin.

\section{INTRODUCTION}

The order Cetacea includes whales, dolphins and porpoises (Berta et al. 2006), animals with distinct characteristics such as reproductive seasonality, polygamous behavior (Schaeff 2007) and a relatively long estrous cycle when compared to terrestrial mammals (Boness 2009).

Correspondence to: Fernanda Menezes de Oliveira e Silva

E-mail: fernanda_fmos@hotmail.com
The reproductive period is related to the seasonality for some cetacean species, such as Sotalia fluviatilis (Best and Da Silva 1984) and occur as a discrete phase together with other aspects such as the presence of food, which differs from Sotalia guianensis. For others, mating happens simultaneously to other activities and the breeding period is identified by the appearance of newborns close to females (Pomeroy et al. 2009). 
The polygamous behavior derives from the long period of calf caring conferred exclusively to females. In some species such as Tursiops truncatus, sequential polygamy occurs, i.e. during the breeding season males are associated with a female for a short time, then leave to find another receptive female (Schaeff 2007).

Some anatomical and reproductive aspects of cetaceans have been studied through macroscopic analysis (Ramos et al. 2000, Best and Da Silva 1984) and have determined the reproductive maturity in females by the presence of corpus albicans, a structure used to measure the number of ovulations since they persist for a lifetime in the ovary in most cetacean species (Berta and Sumich 1999). Other studies evaluated sexual maturity by growth, measuring and weighing the gonads (Santos et al. 2001, Rosas and Monteiro-Filho 2002, Da Silva et al. 2007, Araújo et al. 2007, Katsumata 2010, Perrin and Reilly 1984, Pomeroy 2011). However, studies reporting the microscopic anatomy of the female genital organs are scarce.

Sotalia guianensis is a cetacean from the Suborder Odontoceti (toothed whales) (Berta et al. 2006), commonly called "Guiana dolphin" (MonteiroFilho et al. 2002) or "Estuarine dolphin" (Watson 1988, Daura-Jorge et al. 2005). Some behavioral characteristics of this species, such as lack of sexual dimorphism, preference for turbid waters and escape behavior at human approach, make it difficult to access information about the reproductive parameters such as mating behavior and reproduction period (Santos et al. 2001). Although considered to be the most common dolphin in the Atlantic Ocean, its conservation status is considered by IUCN as data deficient (IUCN 2014).

Given the need for a greater understanding of the reproductive characteristics, a morphological description of the reproductive system is of utmost importance for the conservation of cetaceans and would assist to a better understanding of the reproductive status of females stranded on the Brazilian coast. Thus, the present study aimed to microscopically evaluate genital organs of female Sotalia guianensis stranded in the northeastern coast of Brazil.

\section{MATERIALS AND METHODS}

Four female Sotalia guianensis (a juvenile and three adults), stranded dead in the state of Sergipe, Brazil, were evaluated. Samples of all female genital organs - from the genital slit to the ovaries were provided by Fundação Mamíferos Aquáticos (FMA) and analyzed in Setor de Anatomia dos Animais Domésticos e Silvestres, Faculdade de Medicina Veterinária e Zootecnia, Universidade de São Paulo - FMVZ/USP. All samples were fixed in a $10 \%$ formalin solution.

For light microscopy, tissue fragments were washed in tap water, dehydrated, diaphanized and embedded in Paraplast ${ }^{\circledR}$. Sections $(5-6 \mu m)$ were stained with Hematoxylin-Eosin, Masson's Trichrome and Sirius-red. Then, slides were analyzed by light microscopy (Nikon Eclipse E-800).

For scanning electron microscopy, samples were washed in distilled water and dehydrated underrotation, dried in a critical point apparatus, mounted on aluminum base (stub) using glue carbon, and covered with gold sputting. Images were captured by a scanning electron microscope (LEO 435 VP).

All procedures followed the guidelines of the Ethics Committee for the Use of Animals at the School of Veterinary Medicine and Animal Science at the University of São Paulo, Brazil (Animal Bioethics Protocol 2571/2012). Samples were collected under Sisbio Permit n ${ }^{\circ} 37369-1$.

\section{RESULTS}

The integument of the genital slit and vulva had a thick epidermis, consisting of stratified squamous epithelium forming papillary structures that got into the underlying connective tissue (Fig. 1a and 1b). Differentiated cells were found in the vulvar epithelium but their classification as to type could not be determined (Fig. 1c). 

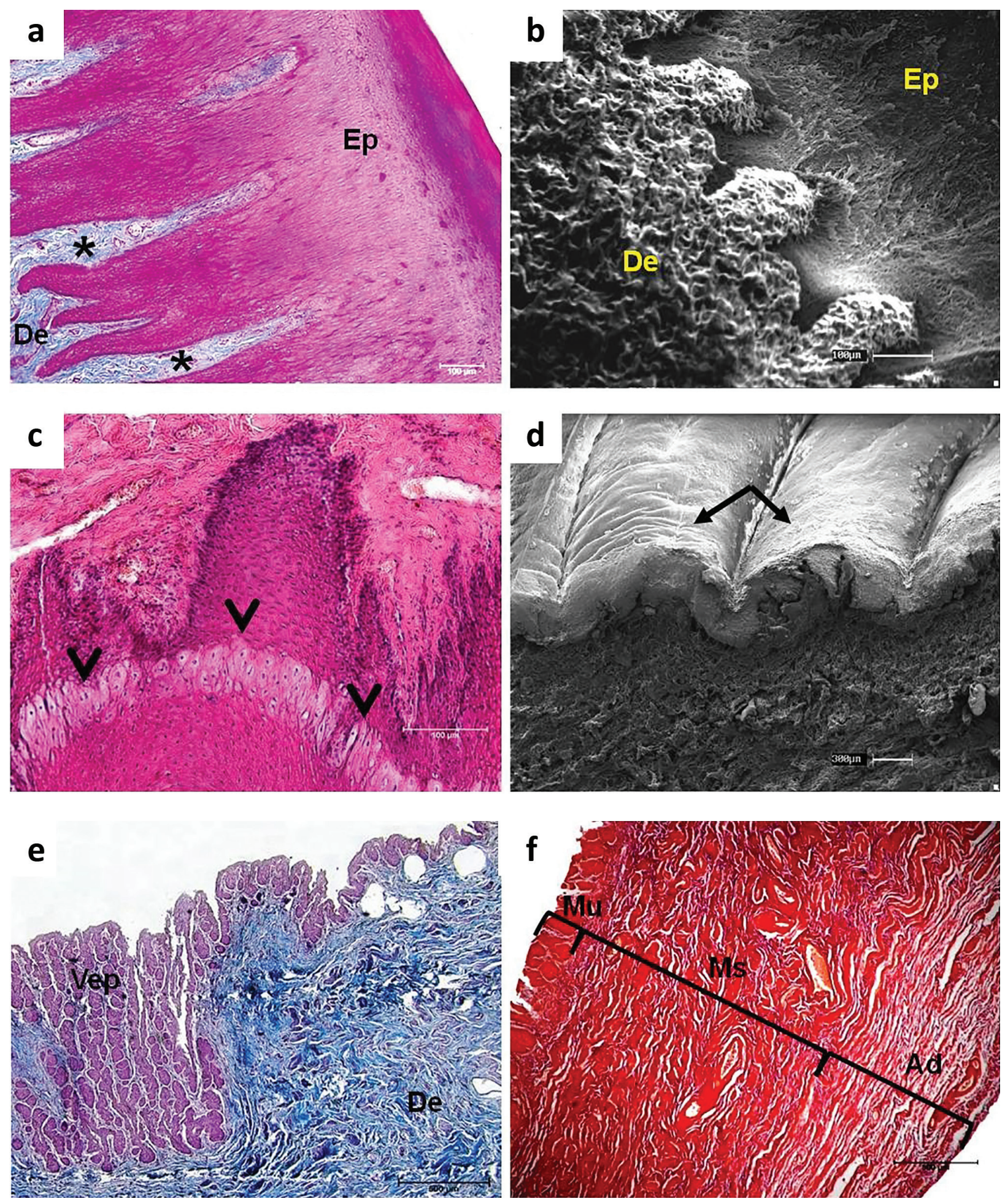

Figure 1 - Photomicrograph of genital slit (a, b), vulva (c, d), and vagina $(\mathbf{e}, \mathbf{f})$ of Sotalia guianensis. a, b. Dermal papillae $(*)$ entering the epidermis. Epidermis (Ep) and dermis (De). a. 10x. Masson's Trichrome (MT). b. Scanning electron photomicrograph. c. Differentiated cells (arrowheads) in the epidermal epithelium of the vulva. 20x. Hematoxylin-Eosin. d. Scanning electron photomicrograph. Presence of longitudinal folds of the mucosa of vulva (arrows). e. Vaginal epithelium (Vep) forming crypts in the dermis (De) underlying. 20x. MT. f. Mucosa (Mu), muscle (Ms) and adventitia (Ad) layers of the vagina. 4x. Sirius-red. 
The dermis was composed of dense and loose vascularized connective tissue that became continuous with the hypodermis (Fig. 1a and 1b). There was no presence of hair follicles or sebaceous and sweat glands. The hypodermis, located below the dermis, was formed by loose connective tissue, consisting of fat cells interspersed with collagen bundles. The vulva of all females had prominent longitudinal folds (Fig. 1d).

The vaginal mucosa epithelial type was identified as non-stratified squamous, forming ridges into the underlying connective tissue (Fig. 1e). The vaginal wall was composed of three distinct layers: tunica mucosa, tunica muscularis and tunica adventitia (Fig. 1f). In all specimens analyzed the vaginal mucosa had longitudinal and transverse flat folds that stretched across its length. The clitoris was not found in any of the fragments analyzed. The tunica muscularis was composed of two layers of smooth muscle, with an inner thick circular layer and a thin longitudinal outer layer. The tunica adventitia was composed of loose connective tissue, where abundant vascularization (Fig. 1f) was observed.

The wall of the uterine cervix of Sotalia guianensis was formed by three layers: mucosa, muscular and serosa (Fig. 2a). The mucosa had prominent longitudinal folds, which could be subdivided into secondary and tertiary. The epithelial lining of the mucosa was simple columnar.

The endometrial stroma was composed of loose connective tissue and contained an extensive vascularization and two layers of smooth muscle. Its inner layer consisted of circular muscle and outer longitudinal layers. Elastic fibers were present in the circular muscle layer and the serous layer consisted of loose connective tissue covered by mesothelium, with numerous blood vessels (Fig. 2b).

The body of the uterus consisted of three layers: perimetrium, myometrium and endometrium. The endometrial epithelium was simple cuboidal, followed by a lamina propria of loose connective tissue. In this lamina there was the presence of endometrial glands and ducts and spiral arterioles which could be easily visualized (Fig. 2c).

Two zones in the endometrium were identified, which differed in both structure and function. The surface layer of the functional area consisted of loose, richly vascularized connective tissue, with high cellularity. The myometrium consisted of a thick inner circular layer and a thin outer longitudinal layer, separated by a stratum vascular, composed of vascular large arteries, veins and lymph vessels that supply the endometrium. The perimetrium consisted of loose connective tissue (Fig. 2c).

The oviducts had a star-shaped lumen, extending from the ovaries to the uterine horns. The inner layer was represented by mucosal folds with a large branched aspect, being composed of a simple columnar epithelium resting on a lamina propria of loose connective tissue (Fig. 2d), followed by a muscular tunic. It was not possible to identify cilia in the oviduct epithelium, due to the condition of samples.

In the connective tissue of the lamina propria, some blood vessels of small caliber occurred. The infundibulum ended in the ovarian bag with a highly folded mucosa (Fig. 2e and 2f).

Ovaries were formed by a cortical and a medullary zone. The cortical portion, peripheral zone, was covered by a simple squamous epithelium containing follicles in various stages of development and corpora lutea (Fig. 3a), with two distinct portions: the tunica albuginea, a dense connective tissue layer and, underlying this, an ovarian stroma containing follicles in various stages of development. The ovarian medulla was constituted of loose connective tissue and blood vessels (Fig. 3b).

The ovarian follicles consisted of an oocyte surrounded by specialized cells (Fig. 3c and 3d). Primordial follicles were composed of an oocyte surrounded by simple squamous epithelium of follicle cells, being found in the outer cortical zone of the ovaries. Ovarian follicles occurred scatteredly in the stroma (Fig. 3c). 

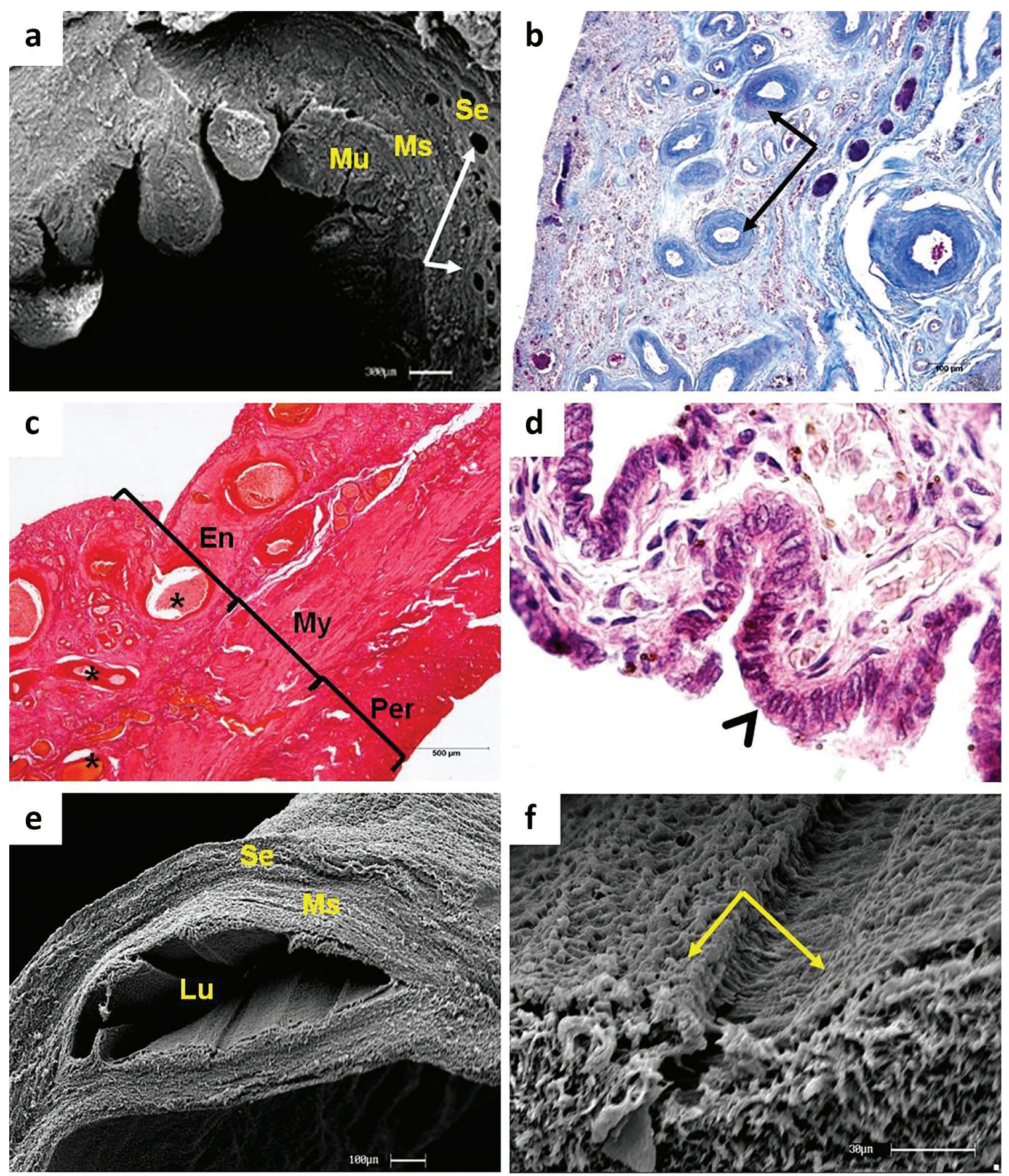

Figure 2 - Photomicrograph of uterine cervix (a), corpus uteri $(\mathbf{b}, \mathbf{c})$ and oviduct $(\mathbf{d}, \mathbf{e}, \mathbf{f})$ of Sotalia guianensis. a. Scanning electron photomicrograph of a cervix from a young female. Mucosa $(\mathrm{Mu})$, muscle $(\mathrm{Ms})$ and serosa (Se) layers with the presence of blood vessels (arrows). b. Blood vessels (arrows) in the uterine submucosa. 10x. Masson's Trichrome. c. Endometrium (En), myometrium (My) and perimetrium (Per). Presence of several blood vessels $\left(^{*}\right)$. 4x. Sirius-red. d. Simple columnar epithelium of the oviduct (arrowhead). 100x. Hematoxylin-Eosin. e, f. Scanning electron photomicrographs. e. Pleated lumen (Lu) of the oviduct mucosa. Muscle (Ms) and serosa (Se) layers. f. Presence of folds (arrows) in the mucosa. 

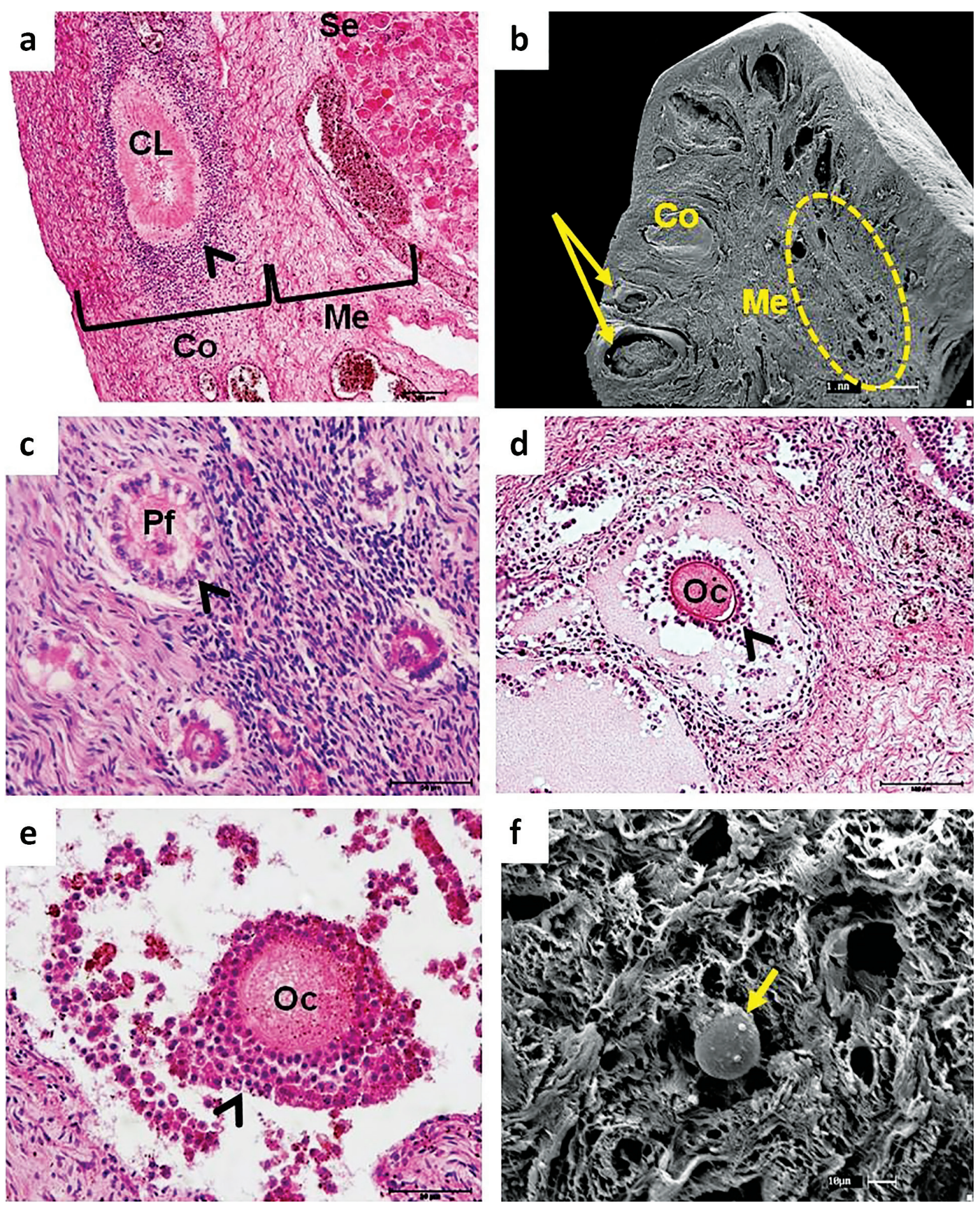

Figure 3 - Photomicrograph of the ovary from Sotalia guianensis. a. Cortical region $(\mathrm{Co})$ with the presence of corpus luteum $(\mathrm{CL})$ in regression. Connective tissue (arrowhead) entering the luteal cells. Medullary region (Me). 10x. Hematoxylin-eosin (HE). b. Ovarian follicles (arrows) in different degrees of development in the cortical region (Co). Presence of blood vessels (highlighted) in the medulla. (Me). 40x. HE. c. Primary follicle (Pf) surrounded by a single layer of follicle cells (arrowhead). 40x. HE. d. Oocyte (Oc) with zona pellucida (arrowhead). 20x. HE. e. Oocyte (Oc) and granulosa cells (arrowhead). 40x. HE. f. Scanning electron photomicrograph. Oocyte (arrow) with few granulosa cells adhered to its surface. 
Secondary follicles were composed of a primary oocyte surrounded by a stratified epithelium of follicular polyhedral cells (granulosa cell). These follicles were marked by the development of the zona pellucida surrounding the oocyte plasma membrane (Fig. 3d).

The tertiary, Antral or Graafian follicles were formed by primary oocytes surrounded by granulosa cells, surrounded by the theca (specialized stromal cells), and a cavity known as antrum (Fig. 3e and 3f). Follicles found in the ovarian stroma were in varying stages of development. Most primordial follicles found had a single layer of follicular cells surrounding the oocyte. The scar tissue that appears with the regression of the corpus luteum is called corpus albicans and from all fragments analyzed only one corpus luteum degeneration could be visualized (Fig. 3a).

\section{DISCUSSION}

Little is known about the microscopic characteristics of the female reproductive system. The genital slit microscopy was similar to those described for the outer skin of cetaceans in general (Berta et al. 2006). Geraci et al. (1986) described this tissue in Tursiops truncatus, reporting a structure consisting of three layers: an outer (epidermis), an intermediate (dermis) layer and a deep layer (hypodermis) composed by adipose tissue.

Parry (1949) observed a distinct feature of the integument of cetaceans while evaluating the species Balaenoptera spp. and Phocoena phocoena: the formation of dermal papillae in subepidermal layer, which are oriented parallel to the axis of the animal's body. This feature was observed in the present study, where numerous finger-like dermal projections step into the thick epidermal layer, which was supported by the dermis and followed by a thick hypodermic layer. Differentiated cells found in the epidermis of the vulva were not similar to any feature described so far; thus, it was not possible to characterize their type.
The vagina in cetaceans, as well as in domestic animals, is a muscular tube that extends from the cervix to the vestibule (Dyce and Wensing 2010). Meek (1918) and Morejohn and Baltz (1972) observed that cetaceans belong to the few mammal groups (including Orders Artiodactyla, Perissodactyla and some species of insectivores such as bats) having vaginal folds. For Slijper (1962), while the outer part of the vagina is smooth with some longitudinal folds, the inner part has a larger number of prominent annular folds, which is similar to a chain funnel with the opening facing the uterine cervix. These features were also found in our study and it is suggested that these folds serve as a barrier to water during swimming and provide extra space to the birth canal, allowing it to extend during birth.

For all females analyzed in this study the vaginal mucosa had longitudinal folds that extended throughout its surface. Such folds differed in some of the analyzed fragments due to analysis of different vaginal portions. Slijper (1979) states that some annular folds are found in the proximal vagina, being called pseudocérvix, thus dividing the vagina into two parts, proximal and distal. Below the epidermal layer, papillary projections were not as prominent as in the genital slit region, but very evident. No clitoris was found in any of the females evaluated. Since no description regarding clitoris in cetaceans was found in the literature, additional studies are necessary in order to clarify this data.

The uterus in toothed whales is similar to that found in other mammals, where the uterine wall is composed of an outer serosa layer, a muscular intermediate layer (consisting of a muscle circularly arranged internally and more longitudinal externally) and endometrium (Simpson and Gardner 1972, Rommel et al. 1993).

For Matthews (1948), in Balaenopteridae, the largest group of baleen whales, the mucosal layer can be further divided into functional areas, being the outer area, a compact layer (which contains the ducts of endometrial glands) and the deepest area, a spongy 
layer. The muscular layer of this group, similar to that of domestic mammals (Bacha and Bacha 2012), consisted of two layers. Between the circular and longitudinal muscle layers, there is a vascular layer consisting of large arteries, veins and lymph vessels supplying the endometrium (Dyce and Wensing 2010). The endometrial stroma was described by Simpson and Gardner (1972), for toothed and baleen whales, as loose connective tissue containing large arterioles. These authors classified the epithelial type overlying the uterine lining as simple cuboid or columnar.

The cyclical variation of the endometrium was described for Balaenopteridae whales by Matthews (1948) who stated that, during ovulation, there is an increase in its thickness. The blood vessels are larger, especially the spongy layer, which has more numerous glands, with some crossing the most superficial layer.

The same histological structure was identified in the analyzed fragments. Functional areas were clearly evident from the visualization of glandular ducts in the stratum compactum and thickened blood vessels in the spongy layer. The tissue observed in the uterine submucosa was classified as loose connective and the mucosal epithelium was simple cuboid, being equivalent to that described in the literature for terrestrial mammals (Bacha and Bacha 2012).

The structure of the oviduct is rarely described for cetaceans. However, researchers such as Honma et al. (2004) described the oviduct of Phocoena phocoena as a highly complex pleated mucosa, full of glands, with fimbriae and a small portion surrounding the ovary. Results found for the oviduct in this study are consistent with the literature, with a star-like shape as the observed in terrestrial mammals (Bacha and Bacha 2012). The mucosa epithelium was simple columnar, being highest in the portion of the bulb, with complex folds. The serous membrane and the stroma of loose connective tissue had high vascularity. The epithelium was highly pleated and the stroma consisted of loose connective tissue.
The histological structure of the ovary of cetaceans is similar to that of terrestrial mammals (Simpson and Gardner 1972). These organs, similar to that of other mammals (Bacha and Bacha 2012), have a cortical portion and an inner medulla. The ovarian histology of a typical mammalian consists of a columnar or squamous germinal epithelium, tunica albuginea, cortex and medulla (Simpson and Gardner 1972), with ovarian follicles in the cortex, in the last fetal stage, containing an oocyte surrounded by a single layer of granulosa cells (Harrison 1974). For Simpson and Gardner (1972), the medullary region is less cellular than the cortex and more vascular, with the presence of collagen fibers.

Some follicles had a space or antral region, separating the oocyte from the follicular cell layer. Slijper (1962) stated that when the follicle matures it becomes distended by the accumulation of fluid within the antrum and moves out of the ovary surface.

Only one structure, identified as atretic corpora lutea, was found in the cortex, filled by connective tissue. Slijper (1962) stated that the atresia of the corpus luteum begins ten days after ovulation. Harrison (1974) warns that one should not mistaken reduced atretic bodies with hyalinized fibrous scarring in toothed whales.

Through our study, it was possible to observe that the structure of organs from the female genital organs of Sotalia guianensis were similar to those found in other terrestrial mammals, with some peculiarities, such as the presence of differentiated cells in the subepidermal layer of the vulva. Due to the fact that existing histological studies for cetaceans are limited, this study provides a unique morphological data, thus contributing to a better knowledge about the biology of this species.

\section{ACKNOWLEDGMENTS}

This work had the financial support of Fundação de Amparo à Pesquisa do Estado de São Paulo (FAPESP Process 2012/20437-1). We thank Fundação Mamíferos Aquáticos for providing all 
samples used in this study as well as the entire staff at FMVZ / USP for their assistance during laboratory analyses. This article employed data generated by Programa Regional de Monitoramento de Encalhes e Anomalidades na Área de Abrangência da Bacia Sergipe-Alagoas carried out by the Fundação Mamíferos Aquáticos and Petrobras, in partnership with Projeto Tamar/ICMBio, as a mitigating measure of the Federal Environmental Licensing conducted by the Brazilian Environmental Agency (IBAMA).

\section{RESUMO}

A morfologia reprodutiva dos cetáceos é pouco estudada e, apesar do grande número de encalhes, dados sobre este assunto são escassos principalmente devido ao acesso às carcaças em um estado avançado de decomposição. O presente estudo teve como objetivo descrever as características histológicas dos órgãos reprodutores femininos de Sotalia guianensis, auxiliando futuros estudos sobre a biologia reprodutiva desses animais. Fêmeas de diferentes idades foram utilizadas, oriundas de eventos de encalhe em praias no nordeste do Brasil. Fragmentos de todos os órgãos foram coletados e processados para microscopia de luz e eletrônica de varredura. As análises histológicas mostraram que estas estruturas eram semelhantes às encontradas em mamíferos terrestres, com algumas particularidades, tais como a presença de células diferenciadas na camada subepidermal vulvar, não descritos na literatura de cetáceos. Os estudos de reprodução com uma descrição morfológica dos órgãos reprodutores femininos são extremamente importantes, uma vez que podem fornecer uma compreensão melhor da fisiologia reprodutiva da espécie, auxiliando no desenvolvimento de novas estratégias para sua conservação.

Palavras-chave: Sistema genital feminino, anatomia, histologia, boto-cinza.

\section{REFERENCES}

Araújo JP, Araújo ME, Souto A, Parente CL and Geise L. 2007. The influence of seasonality, tide and time of activities on the behavior of Sotalia guianensis (Van Bénéden) (Cetacea, Delphinidae) in Pernambuco, Brazil. Rev Bras Zool 24: 1122-1130.
BACHA JR JW AND BACHA LM. 2012. Color Atlas of Veterinary Histology. Iowa: Wiley-Blackwell, 356 p.

BerTA A AND SuMICH JL. 1999. Marine mammals: Evolutionary Biology. Academic Press, 494 p.

BERTA A, Sumich JL AND KovaCs KM. 2006. Marine Mammals: Evolutionary Biology. London: Elsevier, 560 p.

BEST RC AND DA SILVA VMF. 1984. Preliminary analysis of reproductive parameters of the boto, Inia geoffrensis, and the tucuxi, Sotalia fluviatilis, in the Amazon river system. In: Perrin WF et al. (Eds), Reproduction in whales, dolphins and porpoises, Cambridge: International Whaling Commission, Special Issue 6, p. 361-369.

BONESS DJ. 2009. Estrus and Estrous Behavior. In: Perrin WF et al. (Eds), Encyclopedia of marine mammals, San Diego: Academic Press, p. 395-398.

Da Silva VMF, Carter AM, Ambrosio CE, Carvalho AF, Bonatelli M, Lima MC AND Miglino MA. 2007. Placentation in dolphins from the Amazon River Basil: the Boto, Inia geoffrensis, and the Tucuxi, Sotalia fluviatilis. Reprod Biol Endocrinol 5: 26.

DAurA-Jorge FG, WEDEKIn LL, PiACENTINI VQ AND SimÕeS LOPES PC. 2005. Seasonal and daily patterns of group size, cohesion and activity of the estuarine dolphin, Sotalia guianensis (P.J. Van Bénéden), in southern Brazil. Rev Bras Zool 22: 1014-1021.

DyCE KM AND Wensing CJG. 2010. Textbook of veterinary anatomy, London: Saunders, $864 \mathrm{p}$.

GERACI JR, St. AubIN DJ AND HICKS BD. 1986. The epidermis of odontocetes: A view from within. In: Bryden MM et al. (Eds), Research on Dolphins, Oxford: Clarendon Press, p. 3-21.

HARRISON RJ. 1974. Functional anatomy of marine mammals. London: Academic Press, 366 p.

HONMA Y, USHIKI T, HASHIZUME H, TAKEDA M, MATSUISHI T AND HonNo Y. 2004. Histological observations on the reproductive organs of harbour porpoises Phocoena phocoena incidentally caught in a set net installed off Usujiri, southern Hokkaido. Fish Sci 70: 94-99.

IUCN. 2014. IUCN Red List of Threatened Species. Available at: <www.iucnredlist.org>. Downloaded on 01 Aug 2014.

KatSumatA E. 2010. Study on Reproduction of Captive Marine Mammals. J Reprod Dev 56: 1-8.

MatTHEWs LH. 1948. Cyclic Changes in the Uterine Mucosa of Balaenopteridae Whales. J Anat 82: 207-232.

MeEK A. 1918. The reproductive organs of Cetacea. J Anat 52: $186-210$.

Monteiro-Filho ELA, MonteIRo LR AND ReIS SF. 2002. Skull shape and size divergence in dolphins of the genus Sotalia: a tridimensional morphometric analysis. J Mammal 83:125-134.

MOREJOHN VG AND BALTZ DM. 1972. On the reproductive tract of the female Dall porpoise. J Mammal 53: 606-608.

PARRY DA. 1949. The Structure of Whale Blubber, and a Discussion of Its Thermal Properties. In: Berta A et al. (Eds), Marine Mammals: Evolutionary Biology, London: Elsevier, p.132-147. 
PERRIN WF AND REILLY SB. 1984. Reproductive parameters of dolphins and small whales of the family Delphinidae. Rep Int Whal Comm, Spec Issue 6: 97-133.

POMEROY P. 2011. Reproductive cycles of marine mammals. Anim Reprod Sci 124: 184-193.

Pomeroy PP, WILson B AND FEDAK MA. 2009. Reproductive Behavior. In: Perrin WF et al. (Eds), Encyclopedia of marine mammals, San Diego: Academic Press, p. 1015-1026.

RAMOS RMA, DI BENEDITTO APM AND LIMA NRWL. 2000. Growth parameters of Pontoporia blainvillei and Sotalia fluviatilis (Cetacea) in northern Rio de Janeiro, Brazil. Aquatic Mammals 26: 65-75.

ROMMEL SA, PABST DAAND MCLELLAN WA. 1993. Functional morphology of the vascular plexuses associated with the cetacean uterus. Anat Rec 237: 538-546.

RosAs FCW AND MONTEIRO-FILHO ELA. 2002. Reproduction of the estuarine dolphin (Sotalia guianensis) on the coast of Paraná, Southern Brazil. J Mammal 83: 507-515.
SANTOS MCO, ACUÑA LB AND Rosso S. 2001. Insights and calving intervals of the marine tucuxi dolphin (Sotalia fluviatilis) in south-eastern Brazil. J Mar Biol Ass UK 81: 1049-1052.

SCHAEFF CM. 2007. Courtship and Mating Behavior In: Miller DL. Reproductive Biology and Phylogeny of Cetacea. Volume 7, New Hampshire, Science Publishers, p. 349-370.

SIMPSON JG AND GARDNER MB. 1972. Comparative microscopic anatomy of selected marine mammals. In: Ridgway $\mathrm{SH}$ (Ed), Mammals of the Sea-Biology and Medicine, Illinois: Charles C. Thomas, p. 298-418.

SLIJPER EJ. 1962. Whales. London: Hutchinson \& Co., 475 p.

SLIJPER EJ. 1979. Whales. Ithaca: Cornell University Press, 511 p.

WATSON L. 1988. Whales of the World. A complete guide to the world's living whales, dolphins and porpoises. London: Hutchinson \& Co., 302 p. 